\title{
Maternal Iodine Deficiency and Pregnancy Complications: Still a Health Issue for the Pregnant and Fetuses
}

\author{
Ahmed R.G. \\ Division of Anatomy and Embryology, Zoology Department, Faculty of Science, Beni-Suef University, \\ Beni-Suef, Egypt \\ *Corresponding Author: Ahmed R.G., Division of Anatomy and Embryology, Zoology Department, \\ Faculty of Science, Beni-Suef University, Beni-Suef, Egypt
}

\section{LETTER TO EDITOR}

The appropriate maternal thyroxine (T4) and 3,5,3-triiodothyronine (T3) levels during the whole pregnancy are important for the normal fetal development(El-bakry et al., 2010; Ahmed, 2011, 2012a,b, 2013, 2014, 2015a-c, 2016a-d, 2017a-v, 2018a-s; Ahmed and Ahmed, 2012; Ahmed et al., 2008; 2010; 2012; 2013a,b, 2014, 2015a,b, 2018a,b; Ahmed and Incerpi, 2013; Van Herck et al., 2013; Ahmed and El-Gareib, 2014,Incerpi et al., 2014; Candelotti et al., 2015; De Vito et al., 2015; El-Ghareeb et al., 2016; Ahmed and El-Gareib, 2017).In particular, the level of T4 elevates by approximately 50\% during the first trimester of gestation due to estrogen (E2) augmented the concentration of thyroxine binding globulin (TBG) and increased the peripheral T4 metabolism (Morreale de Escobar et al., 2000; Small ridge et al., 2004; Ahmed et al., 2008; Zimmermann, 2016; Tuccilli et al., 2017). The levels of maternal thyroid hormones (THs) depend on the concentration of iodine (Beaufrère et al., 2000; Pearce, 2014; Jin et al., 2017). The level of iodine sharply increases by $50 \%$ during the gestation (Zimmermann, 2016) to increase the production of THs and to cover the fetus needs and the elevation in the iodine excretion (Yarrington and Pearce, 2011). During this stage, fetuses get a fraction of maternal THs and iodine ingredient by the placenta and amniotic fluid.

On the other hand, thyroid disorders, iodine deficiency, and thyroid autoimmunity during the gestation could alter the maternal hemostasis and the fetal development (Chaudhary et al., 2017; Ghanbari and Ghasemi, 2017; Huynh et al., 2017; Lazarus, 2017; Sun et al., 2017; Yu et al., 2017). In addition, Morreale de Escobaret al. (2004) reported that the chronic iodine defects can cause maternal hypothyroidism, and several adverse pregnant disorders. In women, severe maternal iodine deficiency is associated with spontaneous abortion, stillbirth, endemic cretinism, fetal growth restriction (FGR), preterm delivery, low birth weight (LBW), and neurological damage (World Health Organization, 2007; Zimmermann, 2009; Jin et al., 2017). Additionally, Yu et al. (2017) recorded that marginal iodine deficiency can disrupt the interactions between Bergmann glia cells (BGs) and Purkinje cells (PCs), and between the regulation of the glutamate transporter and receptor. Delange (2001) postulated that the gestational inadequate iodine intake can delay the maturation of the developing brain from mild intellectual reduction to frank cretinism, which is the main avoidable reason for mental defects. Nevertheless, the disorders of mild/moderate maternal iodine deficiency on gestation are remaining debated (Mason et al., 2002; Jiskra et al., 2014) on account of its impacts are unstable and mediated (Brucker-Davis et al., 2012).

Collectively, it is also worth mentioning that, together with the previous examinations, the present view suggests that the balance in the activities of THs and in the concentration of iodine during the gestation can keep the regular associations between the dams and their fetuses. In addition, any disorders or deficiency in the concentration of iodine during the gestation may cause multiple pregnancy complications, maternofetal hypothyroidism, and delay the fetal development, in particular, the developing brain. Thus, adjustment the urine iodine concentrations of pregnant women should be followed to avoid any disorders in the maternal iodine and in the fetal development. As well, iodine nutrition or supplementation may be required during the gestation. However, additional 
studies are warranted to investigate the effects of all types of thyroid dysfunctions and gestational iodine nutritional surveillance on the fetal/neonatal outcomes.

\section{REFERENCES}

[1] Ahmed, O.M., Abd El-Tawab, S.M., Ahmed, R.G., 2010. Effects of experimentally induced maternal hypothyroidism and hyperthyroidism on the development of rat offspring: I- The development of the thyroid hormones-neurotransmitters and adenosinergic system interactions. Int. J. Dev. Neurosci. 28, $437-$ 454.

[2] Ahmed, O.M., Ahmed, R.G., 2012. Hypothyroidism. In A New Look At Hypothyroidism. Dr. D. Springer (Ed.), ISBN: 978-953-51-0020-1), In Tech Open Access Publisher, Chapter 1, pp. 1-20.

[3] Ahmed, O.M., Ahmed, R.G., El-Gareib, A.W., El-Bakry, A.M., Abd El-Tawaba, S.M., 2012. Effects of experimentally induced maternal hypothyroidism and hyperthyroidism on the development of rat offspring: II-The developmental pattern of neurons in relation to oxidative stress and antioxidant defense system. Int. J. Dev. Neurosci. 30, 517-537.

[4] Ahmed, O.M., El-Gareib, A.W., El-bakry, A.M., Abd El-Tawab, S.M., Ahmed, R.G., 2008. Thyroid hormones states and brain development interactions. Int. J. Dev. Neurosci. 26(2), 147-209. Review.

[5] Ahmed, R.G., 2011. Perinatal 2, 3, 7, 8-tetrachlorodibenzo-p-dioxin exposure alters developmental neuroendocrine system. Food Chem. Toxicology, 49, 1276-1284.

[6] Ahmed, R.G., 2012a. Maternal-newborn thyroid dysfunction. In the Developmental Neuroendocrinology, pp. 1-369. Ed R.G. Ahmed. Germany: LAP LAMBERT Academic Publishing GmbH \& Co KG.

[7] Ahmed, R.G., 2012b. Maternal-fetal thyroid interactions, Thyroid Hormone, Dr. N.K. Agrawal (Ed.), ISBN: 978-953-51-0678-4, In Tech Open Access Publisher, Chapter 5, pp. 125-156.

[8] Ahmed, R.G., 2013. Early weaning PCB 95 exposure alters the neonatal endocrine system: thyroid adipokine dysfunction. J. Endocrinol. 219 (3), 205-215.

[9] Ahmed, R.G., 2014. Editorial: Do PCBs modify the thyroid-adipokine axis during development? Annals Thyroid Res. 1(1), 11-12.

[10] Ahmed, R.G., 2015a. Chapter 1: Hypothyroidism and brain development. In advances in hypothyroidism treatment. Avid Science Borsigstr.9, 10115 Berlin, Berlin, Germany. Avid Science Publications level 6, Melange Towers, Wing a, Hitec City, Hyderabad, Telangana, India. pp. 1-40.

[11] Ahmed, R.G., 2015b. Hypothyroidism and brain developmental players. Thyroid Research J. 8(2), 1-12.

[12] Ahmed, R.G., 2015c. Editorials and Commentary: Maternofetal thyroid action and brain development. J. of Advances in Biology; 7(1), 1207-1213.

[13] Ahmed, R.G., 2016a. Gestational dexamethasone alters fetal neuroendocrine axis. Toxicology Letters, $258,46-54$.

[14] Ahmed, R.G., 2016b. Neonatal polychlorinated biphenyls-induced endocrine dysfunction. Ann. Thyroid. Res. 2 (1), 34-35.

[15] Ahmed, R.G., 2016c. Maternal iodine deficiency and brain disorders.Endocrinol.Metab.Syndr.5, 223.http://dx.doi.org/10.4172/2161-1017.1000223.

[16] Ahmed, R.G., 2016d. Maternal bisphenol A alters fetal endocrine system: Thyroid adipokine dysfunction. Food Chem. Toxicology, 95, 168-174.

[17] Ahmed, R.G., 2017a. Developmental thyroid diseases and GABAergic dysfunction. EC Neurology 8.1, 02-04.

[18] Ahmed, R.G., 2017b. Hyperthyroidism and developmental dysfunction. Arch Med. 9, 4.

[19] Ahmed, R.G., 2017c. Anti-thyroid drugs may be at higher risk for perinatal thyroid disease. EC Pharmacology and Toxicology 4.4, 140-142.

[20] Ahmed, R.G., 2017d. Perinatal hypothyroidism and cytoskeleton dysfunction. Endocrinol MetabSyndr 6, 271.doi:10.4172/2161-1017.1000271

[21] Ahmed, R.G., 2017e.Developmental thyroid diseases and monoaminergic dysfunction. Advances in Applied Science Research 8(3), 01-10.

[22] Ahmed, R.G., 2017f.Hypothyroidism and brain development.J. Anim Res Nutr.2 (2), 13.

[23] Ahmed, R.G., 2017g. Antiepileptic drugs and developmental neuroendocrine dysfunction: Every why has A Wherefore? Arch Med 9(6), 2.

[24] Ahmed, R.G., 2017h. Gestational pro-oxidant-antioxidant imbalance may be at higher risk for postpartum thyroid disease. EndocrinolMetabSyndr 6, 279. doi:10.4172/2161-1017.1000279. 
[25] Ahmed, R.G., 2017i. Synergistic actions of thyroid-adipokines axis during development. EndocrinolMetabSyndr 6, 280.doi:10.4172/2161-1017.1000280.

[26] Ahmed, R.G., 2017j. Thyroid-insulin dysfunction during development. International Journal of Research Studies in Zoology 3(4), 73-75. DOI: http://dx.doi.org/10.20431/2454-941X.0304010.

[27] Ahmed, R.G., 2017k. Developmental thyroid diseases and cholinergic imbalance. International Journal of Research Studies in Zoology 3(4), 70-72. DOI: http://dx.doi.org/10.20431/2454-941X.0304009.

[28] Ahmed, R.G., 20171. Thyroid diseases and developmental adenosinergic imbalance. Int J ClinEndocrinol $1(2), 053-055$.

[29] Ahmed, R.G., 2017m.Maternal anticancer drugs and fetal neuroendocrine dysfunction in experimental animals. EndocrinolMetabSyndr 6, 281.doi:10.4172/2161-1017.1000281.

[30] Ahmed, R.G., 2017n. Letter: Gestational dexamethasone may be at higher risk for thyroid disease developing peripartum. Open Journal of Biomedical \& Life Sciences (Ojbili) 3(2), 01-06.

[31] Ahmed, R.G., 2017o.Deiodinases and developmental hypothyroidism. EC Nutrition 11.5, 183-185.

[32] Ahmed, R.G., 2017p.Maternofetal thyroid hormones and risk of diabetes. Int. J. of Res. Studies in Medical and Health Sciences 2(10), 18-21.

[33] Ahmed, R.G., 2017r.Association between hypothyroidism and renal dysfunctions. International Journal of Research Studies in Medical and Health Sciences 2(11), 1-4.

[34] Ahmed, R.G., 2017s.Maternal hypothyroidism and lung dysfunction. International Journal of Research Studies in Medical and Health Sciences 2(11), 8-11.

[35] Ahmed, R.G., 2017t.Endocrine disruptors; possible mechanisms for inducing developmental disorders. International journal of basic science in medicine (IJBSM) 2(4), 157-160.

[36] Ahmed, R.G., 2017u.Maternal thyroid hormones trajectories and neonatal behavioral disorders. ARC Journal of Diabetes and Endocrinology 3(2), 18-21.

[37] Ahmed, R.G., 2017v.Maternal thyroid dysfunction and neonatal cardiac disorders. Insights Biol Med. 1, 092-096.

[38] Ahmed, R.G., 2018a. Maternal hypothyroidism and neonatal testicular dysfunction. International Journal of Research Studies in Medical and Health Sciences 3(1), 8-12.

[39] Ahmed, R.G., 2018b. Maternal hypothyroidism and neonatal depression: Current perspective. International Journal of Research Studies in Zoology 4(1), 6-10. DOI: http://dx.doi.org/10.20431/2454-941X.0401002.

[40] Ahmed, R.G., 2018c. Non-genomic actions of thyroid hormones during development. App ClinPharmacolToxicol: ACPT-108. DOI: 10.29011/ACPT-109. 100008.

[41] Ahmed, R.G., 2018d. Maternal thyroid function and placental hemodynamic. ARC Journal of Animal and Veterinary Sciences 4(1), 9-13. DOI: http://dx.doi.org/10.20431/2455-2518.0401002.

[42] Ahmed, R.G., 2018e.Interactions between thyroid and growth factors during development. ARC Journal of Diabetes and Endocrinology 4(1), 1-4. DOI: http://dx.doi.org/10.20431/2455-5983.0401001.

[43] Ahmed, R.G., 2018f. Maternal thyroid hormones and neonatal appetite. ARC Journal of Nutrition and Growth 4(1), 18-22. DOI: http://dx.doi.org/10.20431/2455-2550.0401005.

[44] Ahmed, R.G., 2018g. Genomic actions of thyroid hormones during development. ARC Journal of Diabetes and Endocrinology 4(1), 5-8. DOI: http://dx.doi.org/10.20431/2455-5983.0401002.

[45] Ahmed, R.G., 2018h. Dysfunction of maternal thyroid hormones and psychiatric symptoms. American Research Journal of Endocrinology. 2(1), 1-6.

[46] Ahmed, R.G., 2018i. Is there a connection between maternal hypothyroidism and developing autism spectrum disorders? ARC Journal of Neuroscience 3(1), 5-8. DOI: http://dx.doi.org/10.20431/2456057X.0301002.

[47] Ahmed, R.G., 2018j.Maternal thyroid dysfunctions and neonatal bone maldevelopment.American Research Journal of Endocrinology (In press) xx-xxx.

[48] Ahmed, R.G., 2018k. Maternal thyroid disorders and risk of neonatal seizure: Current perspective. ARC Journal of Neuroscience 3(1), 21-25. DOI: http://dx.doi.org/10.20431/2456-057X.0301004

[49] Ahmed, R.G., 20181. Gestational dioxin acts as developing neuroendocrine-disruptor. EC Pharmacology and Toxicology 6.3, 96-100.

[50] Ahmed, R.G., 2018m.Maternal thyroid dysfunction and risk of neonatal stroke. ARC Journal of Animal and Veterinary Sciences 4(1), 22-26. DOI: http://dx.doi.org/10.20431/2455-2518.0401004

[51] Ahmed, R.G., 2018n. Maternal thyroid disorders and developing skin dysfunctions. ARC Journal of Dermatology 3(1), 13-17. DOI: http://dx.doi.org/10.20431/2456-0022.0301005 
[52] Ahmed, R.G., 2018o. Maternal hypothyroidism-milk ejections: What is the link? ARC Journal of Nutrition and Growth 4(1), 29-33. DOI: http://dx.doi.org/10.20431/2455-2550.0401007

[53] Ahmed, R.G., 2018p. Does maternal antepartum hypothyroidism cause fetal and neonatal hyponatremia?ARC Journal of Diabetes and Endocrinology 4(1), xx-xxx. DOI: http://dx.doi.org/10.20431/2455-5983.0401004

[54] Ahmed, R.G., 2018q. Maternal hypothyroidism and rheumatoid arthritis. International Journal of Research Studies in Medical and Health Sciences Volume 3(2), 1-5.

[55] Ahmed, R.G., 2018r. Developmental thyroid and skeletal muscle dysfunction.ARC Journal of Diabetes and Endocrinology 4(1), xx-xxx. DOI: http://dx.doi.org/10.20431/2455-5983.0401003.

[56] Ahmed, R.G., 2018s.Hyperthyroidism and renal disorders. ARC Journal of Animal and Veterinary Sciences 4(2), 1-5. DOI: http://dx.doi.org/10.20431/2455-2518.0402001

[57] Ahmed, R.G., Abdel-Latif, M., Ahmed F., 2015a.Protective effects of GM-CSF in experimental neonatal hypothyroidism. International Immunopharmacology 29, 538-543.

[58] Ahmed, R.G., Abdel-Latif, M., Mahdi, E., El-Nesr, K., 2015b. Immune stimulation improves endocrine and neural fetal outcomes in a model of maternofetal thyrotoxicosis. Int. Immunopharmacol. 29, 714-721.

[59] Ahmed, R.G., Davis, P.J., Davis, F.B., De Vito, P., Farias, R.N., Luly, P., Pedersen, J.Z., Incerpi, S., 2013a. Nongenomic actions of thyroid hormones: from basic research to clinical applications. An update. Immunology, Endocrine \& Metabolic Agents in Medicinal Chemistry, 13(1), 46-59.

[60] Ahmed, R.G., El-Gareib, A.W. 2014.Lactating PTU exposure: I- Alters thyroid-neural axis in neonatal cerebellum. Eur. J. of Biol. and Medical Sci. Res. 2(1), 1-16.

[61] Ahmed, R.G., El-Gareib, A.W., 2017.Maternal carbamazepine alters fetal neuroendocrine-cytokines axis. Toxicology 382, 59-66.

[62] Ahmed, R.G., El-Gareib, A.W., Incerpi, S., 2014. Lactating PTU exposure: II- Alter's thyroid-axis and prooxidant-antioxidant balance in neonatal cerebellum. Int. Res. J. of Natural Sciences 2(1), 1-20.

[63] Ahmed, R.G., El-Gareib, A.W., Shaker, H.M., 2018a.Gestational 3, 3', 4, 4', 5-pentachlorobiphenyl (PCB 126) exposure disrupts fetoplacental unit: Fetal thyroid-cytokines dysfunction. Life Sciences 192, 213220.

[64] Ahmed, R.G., Incerpi, S., 2013. Gestational doxorubicin alters fetal thyroid-brain axis. Int. J. Devl. Neuroscience 31, 96-104.

[65] Ahmed, R.G., Incerpi, S., Ahmed, F., Gaber, A., 2013b. The developmental and physiological interactions between free radicals and antioxidant: Effect of environmental pollutants. J. of Natural Sci. Res. 3(13), 74110.

[66] Ahmed, R.G., Walaa G.H., Asmaa F.S., 2018b.Suppressive effects of neonatal bisphenol A on the neuroendocrine system. Toxicology and Industrial Health Journal (in press).

[67] Beaufrère, B., Bresson, J., Briend, A., 2000. Iodine nutrition in the infant. Committee on Nutrition of the French Society of Pediatrics. Arch Pediatr. 7(1), 66-74.

[68] Brucker-Davis, F., Ferrari, P., Gal, J., 2012. Iodine status has no impact on thyroid function in early healthy pregnancy. J Thyroid Res. 2012, 168-76.

[69] Candelotti, E., De Vito, P., Ahmed, R.G., Luly, P., Davis, P.J., Pedersen, J.Z., Lin, H-Y., Incerpi, I., 2015. Thyroid hormones crosstalk with growth factors: Old facts and new hypotheses. Immun., Endoc. \& Metab. Agents in Med. Chem., 15, 71-85.

[70] Chaudhary, L.N., Khatiwada, S., Gelal, B., Gautam, S., Lamsal, M., Pokharel, H., Baral, N., 2017. Iodine and thyroid functional status, and anti-thyroid peroxidase antibody among pregnant women in Eastern Nepal. J Nepal Health Res Counc. 15(2), 114-119.

[71] De Vito, P., Candelotti, E., Ahmed, R.G., Luly, P., Davis, P.J., Incerpi, S., Pedersen, J.Z., 2015.Role of thyroid hormones in insulin resistance and diabetes. Immun., Endoc. \& Metab. Agents in Med. Chem., 15, 86-93.

[72] Delange, F., 2001.Iodine deficiency as a cause of brain damage. Postgrad Med J 77, 217-220.

[73] El-bakry, A.M., El-Ghareeb, A.W., Ahmed, R.G., 2010.Comparative study of the effects of experimentally-induced hypothyroidism and hyperthyroidism in some brain regions in albino rats. Int. J. Dev. Neurosci. 28, 371-389.

[74] El-Ghareeb, A.A., El-Bakry, A.M., Ahmed, R.G., Gaber, A., 2016.Effects of zinc supplementation in neonatal hypothyroidism and cerebellar distortion induced by maternal carbimazole. Asian Journal of Applied Sciences 4(04), 1030-1040. 
[75] Ghanbari, M., Ghasemi, A., 2017. Maternal hypothyroidism: An overview of current experimental models. Life 187, 1-8.

[76] Huynh, D., Condo, D., Gibson, R., Muhlhausler, B., Ryan, P., Skeaff, S., Makrides, M., Zhou, S.J., 2017. Iodine status of postpartum women and their infants in Australia after the introduction of mandatory iodine fortification.Br J Nutr. 117(12), 1656-1662.

[77] Incerpi, S., Hsieh, M-T., Lin, H-Y., Cheng, G-Y., De Vito, P., Fiore, A.M., Ahmed, R.G., Salvia, R., Candelotti, E., Leone, S., Luly, P., Pedersen, J.Z., Davis, F.B., Davis, P.J., 2014. Thyroid hormone inhibition in L6 myoblasts of IGF-I-mediated glucose uptake and proliferation: new roles for integrin avß3. Am. J. Physiol. Cell Physiol. 307, C150-C161.

[78] Jin, Y., Yang, L., Hongjie, L., Heming, Z., Xiaofeng, L., Lin, Z., Zhe, W., 2017. Associations of maternal iodine status and thyroid function with adverse pregnancy outcomes in Henan Province of China. Journal of Trace Elements in Medicine and Biology xx-xxx.

[79] Jiskra, J., Fait, T., Bílek, R., 2014. Mild iodine deficiency in women after spontaneous abortions living in an iodine-sufficient area of Czech Republic: prevalence and impact on reproductive health. ClinEndocrinol (Oxf). 80(3), 452-458.

[80] Lazarus, J.H., 2017.Role of the Iodine Global Network in Elimination of Iodine Deficiency. Recent 10(2), 119-122.

[81] Mason, J.B., Deitchler, M., Gilman, A., 2002. Iodine fortification is related to increased weight-for-age and birth weight in children in Asia. Food Nutr Bull. 23(3), 292-308.

[82] Morreale de Escobar, G., Obregon, M.J., Escobar Del Rey, F., 2000. Is neuropsychological development related to maternal hypothyroidism or to maternal hypothyroxinemia? J ClinEndocrinolMetab 85, 75-87.

[83] Morreale de Escobar, G., Obregon, M.J., Escobar Del Rey, F., 2004. Role of thyroid hormone during early brain development. European Journal of Endocrinol.151 (supply 3), U25-U37.

[84] Pearce, E.N., 2014. Iodine deficiency in children. Endocr Dev. 26, 130-138.

[85] Small ridge, R.C., Glinoer, D., Hollowell, J.G., Brent, G., 2004. Thyroid function inside and outside of pregnancy: what do we know and what don't we know. Thyroid 15, 54-9.

[86] Sun, X., Lu, L., Shan, L., Shan, Z., Teng, W., 2017.Iodine Storage and Metabolism of Mild to Moderate Iodine-Deficient Pregnant Rats. Thyroid 27(6), 846-851.

[87] Tuccilli, C., Baldini, E., Truppa, E., D'Auria, B., De Quattro, D., Cacciola, G., 2017. Iodine deficiency in pregnancy: still a health issue for the women of cassino city. J. Nutrition XX-Xxx.

[88] Van Herck, S.L.J., Geysens, S., Bald, E., Chwatko, G., Delezie, E., Dianati, E., Ahmed, R.G., Darras, V.M., 2013.Maternal transfer of methimazole and effects on thyroid hormone availability in embryonic tissues. Endocrinol. 218, 105-115.

[89] World Health Organization, 2007.Assessment of Iodine Deficiency Disorders and Monitoring Their Elimination, $2^{\text {nd }}$ edn. Geneva: WHO.

[90] Yarrington, C., Pearce, E.N., 2011. Iodine and Pregnancy. J Thyroid Res 2011, 93-104.

[91] Yu, Y., Dong, J., Wang, Y., Wang, Y., Min, H., Shan, Z.Y., Teng, W.P., Chen, J., 2017.Effects of maternal marginal iodine deficiency on interactions between cerebellar Bergmann Glia cells and Purkinje cells in rat offspring. Biomed 30(12), 932-937.

[92] Zimmermann, M.B., 2009. Iodine deficiency. Endocrine Reviews. 30(4), 376-408.

[93] Zimmermann, M.B., 2016.The importance of adequate iodine during pregnancy and infancy. World Rev Nutr Diet 115, 118-24.

Citation: R.G. Ahmed, "Maternal Iodine Deficiency And Pregnancy Complications: Still A Health Issue For The Pregnant And Fetuses", ARC Journal of Pharmaceutical Sciences (AJPS) , vol. 4, no. 1, p. 7-11, 2018. http://dx.doi.org/10.20431/2455-1538.0401002

Copyright: (C) 2018 Authors. This is an open-access article distributed under the terms of the Creative Commons Attribution License, which permits unrestricted use, distribution, and reproduction in any medium, provided the original author and source are credited 